\title{
Pengaruh Evaluasi Kinerja Terhadap Komitmen Organisasional Karyawan
}

\author{
Asep Rudi Hartono $^{1 *}$ dan Maya Setiawardani ${ }^{2}$ \\ 1 Jurusan Administrasi Niaga, Politeknik Negeri Bandung, Indonesia \\ 2 Jurusan Administrasi Niaga, Politeknik Negeri Bandung, Indonesia
}

\begin{abstract}
:
This study examines the company's performance appraisal, employee's organizational commitment and the influence of organizational commitment on employee's performance appraisal in PT Indonesia Power UBP Suralaya. The dataset encompasses observations using questionnaire (195 respondents). The methods of analysis in this research are classical assumption test, descriptive analysis, correlation, linear regression, and test hypotheses using the SPSS program. Research results show that the performance appraisal is already good, and organizational commitment of employees are already high. There is a strong link between performance appraisal with the organizational commitment of employees. The influence of performance appraisal has positive effect for $46.6 \%$ on the organizational commitment of employees while the rest $53.4 \%$ is affected by other factors such as job satisfaction, job characteristics and other factors which are not examined in this study.
\end{abstract}

Keywords: human resources, organizational commitment, performance appraisal

\section{PENDAHULUAN}

\section{Latar Belakang Penelitian}

Manajemen sumber daya manusia dapat diartikan sebagai ilmu yang mangatur hubungan dan peranan tenaga kerja secara efektif dan efisien sehingga tercapai tujuan organisasi atau perusahaan. Manajemen sumber daya manusia dapat juga diartikan sebagai kegiatan perencanaan, pengorganisasian, pengarahan dan pengendalian atas pengadaan tenaga kerja, pengembangan, kompensasi, integritas pemeliharaan dan pemutusan hubungan kerja dengan sumber daya manusia untuk mencapai sasaran perorangan, organisasi dan masyarakat (Flippo, 1996 dalam Yani, 2012). Dengan kata lain secara lugas manajemen sumber daya manusia memiliki pengertian sebagai kegiatan perencanaan, pengadaan, pengembangan, pemeliharaan dan

*Email korespondensi:

Asep Rudi Hartono

arh_rudihartono@yahoo.com penggunaan sumber daya manusia dalam upaya mencapai tujuan individu ataupun organisasional.

Evaluasi kinerja merupakan mekanisme penting bagi manajemen sumber daya manusia untuk digunakan dalam menjelaskan tujuan dan standar kinerja, memotivasi kinerja individu dan menjadi basis bagi keputusan-keputusan yang mempengaruhi gaji, promosi, pemberhentian, pelatihan, transfer dan kondisi kepegawaian lainnya. Evaluasi kinerja terhadap suatu perusahaan merupakan suatu tahap evaluasi kerja yang dapat meningkatkan kualitas pekerjaan bagi kelangsungan aktivitas perusahaan di dalamnya. Pekerjaan yang diinginkan oleh perusahaan terhadap para pekerja memiliki standar mutu (quality) untuk mengukur keberhasilan kerja. Namun kualitas kerja dari beberapa pekerja tidak selamanya sesuai dengan standar mutu yang diberlakukan. Suatu saat situasi dan kondisi tidak memungkinkan untuk mencapai tujuan dan 
harapan perusahaan tersebut, sehingga menyebabkan penilaian terhadap prestasi kerja yang dihasilkan (performance) menjadi menurun.

Menurut Wirawan (2015: 11) evaluasi kinerja merupakan peroses penilaipejabat yang melakukan penilaian (appraiser) mengumpulkan informasi mengenai kinerja ternilai-pegawai yang dinilai (appraise) yang didokumentasikan secara formal untuk menilai kinerja ternilai dengan membandingkannya dengan standar kinerja secara periodik untuk membantu pengambilan keputusan manajemen sumber daya manusia. Sedangakan menurut Wayne F. Cascio (1989) dalam Wirawan (2015: 12) mendifinisikan "performance appraisal is the systematic description of an employee's job relavant strengths and weakness".

Sistem evaluasi kinerja yang efektif dan efisien memerlukan sejumlah persyaratan agar menguntungkan organisasi dan karyawan yang bekerja untuk organisasi. Persyaratan tersebut antara lain menurut Wirawan (2015: 117) adalah relevansi, reliabilitas, sensitivitas, akseptabilitas, praktikal dan tidak melanggar undangundang. Evaluasi kinerja harus dilaksanakan secara objektif sesuai dengan teori dalam ilmu evaluasi kinerja. Ketidakobjektifan melaksanakan evaluasi kinerja akan menimbulkan masalah hubungan industrial. Evaluasi kinerja tidak boleh dilakukan berdasarkan suka atau tidak suka penilai terhadap ternilai. Jika hal ini terjadi, evaluasi kinerja akan menjadi tidak produktif. Oleh karena itu, pelaksanaan evaluasi kinerja perlu memperhatikan norma-norma etika. Menurut Wirawan (2015: 130) norma-norma evaluasi kinerja adalah keadilan prosedural, keadilan distributif, keadilan interaksional, persamaan, tidak adanya diskriminasi, terbuka, rahasia, dan tidak adanya kebohongan.

Suatu sistem evaluasi kinerja yang disusun berdasarkan teori ilmu evaluasi kinerja dan dilaksanakan secara objektif akan berdampak positif bagi para pegawai atau karyawan dan organisasi. Penelitian menunjukan adanya hubungan antara evaluasi kinerja dengan kepuasan kerja. Evaluasi kinerja yang diterima dengan baik oleh para pegawai dapat meningkatkan kepuasan kerja, motivasi kerja, komitmen organisasi, mengurangi tingkat absen, dan pindah kerja (turnover). Demikian sebaliknya apabila evalusi kinerja tidak dapat diterima dengan baik oleh para pegawai dapat menurunkan kepuasan kerja, komitmen organisasi, dan kondisi kepegawaian lainnya (Wirawan, 2015: 136).

Komitmen organisasional adalah salah satu hal yang dipengaruhi oleh evaluasi kinerja yaitu apabila evaluasi kinerja dapat diterima dengan baik oleh para pegawai maka komitmen organisasi pegawai akan meningkat, sedangkan apabila evaluasi kinerja tidak dapat diterima dengan baik oleh para pegawai maka akan menurunkan komitmen organisasional pegawai. Menurut Luthans (2011: 147) dalam Wibowo (2015: 188), komitmen organisasional didefinisikan sebagai sebuah keinginan kuat untuk tetap menjadi anggota organisasi tertentu, keinginan untuk mendesak usaha pada tingkat tinggi atas nama organisasi, dan keyakinan yang pasti dalam menerima dan atas nilai-nilai dan tujuan organisasi.

Meyer dan Allen dalam Wibowo (2015: 189) menyebutkan tipe atau dimensi komitmen adalah affective commitment yaitu menyangkut keterkaitan emosional pekerja pada identifikasi dengan dan pelibatan dalam organisasi, continuance commitment yaitu komitmen didasarkan pada biaya yang bersangkutan dengan pekerja dengan meninggalkan organisasi, normative commitment menyangkut perasaan pekerja atas kewajiban untuk tetap tinggal dengan perusahaan atau organisasi karena itu merupakan yang terbaik untuk dilakukan.

PT Indonesia Power, atau IP, adalah sebuah anak perusahaan PLN menjalankan usaha komersial pada bidang pembangkitan tenaga listrik. Saat ini Indonesia Power merupakan perusahaan pembangkitan listrik dengan daya mampu terbesar di Indonesia. Cikal bakal perusahaan ini adalah PT 


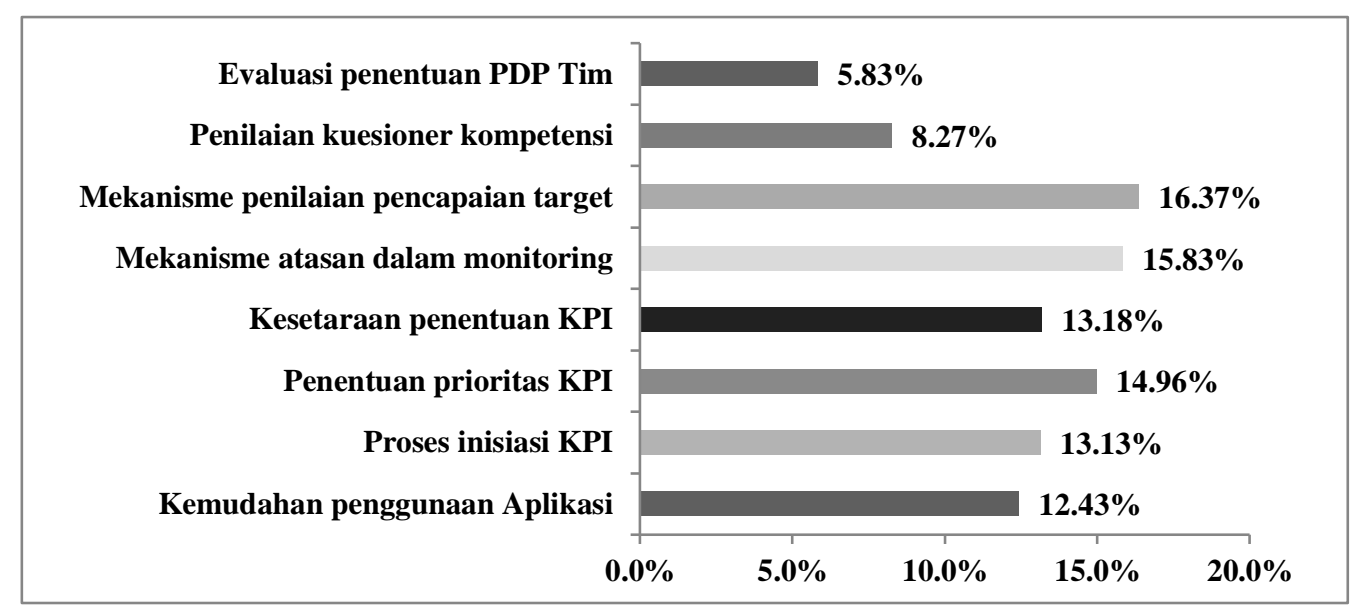

Gambar 1. Survey Kepuasaan Evaluasi Kinerja Februari 2016 (Sumber: PT. Indonesia Power)

Pembangkitan Tenaga Listrik Jawa-Bali I (PLN PJB I), yang didirikan pada tanggal 3 Oktober 1995 sebagai anak perusahaan PLN yang waktu itu baru saja berubah statusnya dari Perum menjadi Persero. Pada tanggal 3 Oktober 2000, PJB I berubah nama menjadi PT Indonesia Power. Indonesia Power mengelola 8 Unit Bisnis Pembangkitan: Priok, Suralaya, Saguling, Kamojang, Mrica, Semarang, Perak-Grati dan Bali. Bisnis utama IP adalah pengoperasian pembangkit listrik di Jawa dan Bali yang tersebar di 8 lokasi. Unit usaha pembangkitan IP diberi nama Unit Bisnis Pembangkitan (UBP).

Salah satu Unit Bisnis Pembangkitan (UBP) adalah UBP Suralaya yang beralamat di komplek PLTU Suralaya no 15 Merak, Serang - Banten. Dengan jumlah pegawai 709 orang per februari 2016. Sebagai perusahaan besar dengan jumlah karyawan yang banyak tentunya PT Indonesia Power memiliki manajemen untuk mengelola sumber daya manusia yang ada diperusahan. Salah satu program manajemen sumber daya manusia PT Indonesia Power UBP Suralaya adalah dengan melakukan evaluasi kinerja pegawai secara berkala.

Berdasarkan hasil wawancara tidak terstruktur yang dilakukan peneliti tanggal 22 Februari 2016 pada bagian budaya perusahaan, berdasarkan hasil survey yang dilakukan manajemen perusahaan diperoleh hasil yaitu rendahnya kepuasan pegawai terhadap sistem evaluasi kinerja yang dilakukan perusahaan hal tersebut mengindikasikan terdapat permasalahan mengenai evaluasi kinerja yang dilakukan perusahaan. Hasil survey tersebut dapat dilihat dari data survey kepuasan pegawai mengenai sistem evalusi kinerja yang cenderung rendah pada gambar 1 .

Dari grafik diatas diketahui bahwa hasil survey mengenai tingkat kepuasan karyawan terhadap evaluasi kinerja yang dilakukan relatif rendah yang artinya sistem evalusi kinerja yang ada atau pelaksanaan evaluasi kinerja masih dipandang kurang objektif. Rata rata tingkat kepuasan karyawan adalah $12,50 \%$ dengan persentase tertinggi adalah 16,37 \% yaitu mengenai mekanisme penilaian pencapaian target dan persentase terendah adalah $5,83 \%$ yaitu mengenai evaluasi penentuan program Pengembangan Diri Pegawai (PDP Tim).

Dari hasil wawancara tidak tersetruktur yang dilakukan peneliti terhadap salah satu karyawan diperoleh alasan mengenai ketidakpuasan tersebut diantaranya adalah kurangnya sosialiasi mengenai kompetensi dan evaluasi kinerja, tidak terbukanya atasan yang melakukan penilaian dan belum adanya pemahaman yang jelas mengenai penilaian kinerja. Dari hasil wawancara peneliti tidak dapat menyimpulkan bahwa alasan tersebut dapat mewakili ketidakpuasan yang dirasakan oleh 
Tabel 1 Survey GCG dan Kepatuhan

\begin{tabular}{|c|c|c|c|c|c|c|c|c|}
\hline \multirow{2}{*}{ No } & \multirow{2}{*}{ Indikator Kinerja Kunci } & \multirow{2}{*}{ Satuan } & \multirow{2}{*}{ Bobot } & \multirow{2}{*}{ Target } & \multicolumn{2}{|c|}{ Realisasi } & \multirow{2}{*}{ KKU } & \multirow{2}{*}{ KET } \\
\hline & & & & & SM 1 & SM 2 & & \\
\hline $\mathrm{V}$ & $\begin{array}{l}\text { Kepemimpian, tata kelola } \\
\text { dan tanggung jawab } \\
\text { kemasyarakatan }\end{array}$ & & 12 & & & & 12 & \\
\hline 1 & $\begin{array}{l}\text { Penerapan GCG dan } \\
\text { Kepatuhan }\end{array}$ & $\%$ & 6 & 95 & 97,5 & 94,83 & 5,99 & Hati-hati \\
\hline 2 & $\begin{array}{l}\text { Penerapan K3, } \\
\text { Lingkungan dan CSR }\end{array}$ & Level & 6 & 4 & 4 & 4,02 & 6 & Baik \\
\hline
\end{tabular}

(Sumber: PT. Indonesia Power)

seluruh karyawan mengenai sistem evaluasi kinerja yang dilakukan perusahaan, maka peneliti melanjutkan penelitian dengan menyebar kuesioner kepada karyawan dengan jumlah atau sumber yang refresentatif.

Manajemen menghawatirkan kekurangefektifan mengenai sistem evaluasi kinerja tersebut dapat mempengaruhi komitmen organisasional pegawai, dikarenakan hasil survey yang dilakukan di semester 2 tahun 2015 Good Corporate Govenance $(G C G)$ dan kepatuhan pada posisi hati-hati atau perlu perhatian. Data tersebut dapat di lihat pada tabel 1 .

Dari tabel 1 tersebut, realisasi penerapan Good Corporate Governance $(G C G)$ dan kepatuhan adalah $94,83 \%$ nilai tersebut tidak mencapai target pada semester II dengan persentase target $95 \%$ sesuai standar perusahaan realisasi sebesar $94,83 \%$ berada pada posisi hati-hati atau perlu perhatian agar lebih baik lagi sehingga dapat tercapai sesuai dengan target yang telah ditentukan. Selain itu hasil survey $94.83 \%$ juga dikatakan menurun dari sebelumnya. Pada tahun 2015 semester I survey kepatuhan dan Good Corporate Governance (GCG) mencapai $97,5 \%$ atau dikatakan baik karena melebihi target yang telah ditentukan yaitu $95 \%$.

Survey Good Corporate Governance $(G C G)$ dan kepatuhan adalah survey yang dilakukan manajemen untuk melihat atau menilai seberapa besar komitmen/ kepatuhan dan Good Corporate Governance (GCG) dan seberapa memahaminya pegawai mengenai pedoman kerja tersebut. Good Corporate Governance (GCG) adalah pedoman kebijakan tata kelola perusahaan, pedoman etika perusahaan (Code of Conduct, COC), pedoman kerja, pedoman pengelolaan perusahaan, pedoman kebijakan manajemen risiko, pedoman sistem pengendalian internal, serta kebijakan-kebijakan lainnya untuk mendukung praktik tata kelola perusahaan seperti kebijakan whistle blowing system, kebijakan pengendalian gratifikasi, kebijakan laporan harta kekayaan pejabat perusahaan, kebijakan indonesia power bersih, kebijakan benturan kepentingan, kebijakan transparansi informasi publik.

Perusahaan memandang praktik tata kelola perusahaan yang baik merupakan alat untuk menjaga kelangsungan usaha, menjaga kepercayaan para pemangku kepentingan dan menumbuhkan integritas perusahaan. Pedoman Tata Kelola Perusahaan disusun sebagai acuan dalam mengelola PT Indonesia Power berdasarkan prinsip Good Corporate Governance (GCG) yang menjadi kaidah dan pedoman bagi pengurus Perusahaan dalam menjalankan aktivitas bisnisnya. Maka peningkatan kepatuhan pegawai sebagai komitmen organisasional terhadap aturan perusahaan perlu diperhatikan dengan baik.

Berdasarkan permasalahan yang terjadi, peneliti berpendapat tedapat hubungan antara ketidakpuasan mengenai sistem evaluasi kinerja dengan menurunnya komitmen organisasi pegawai PT Indonesia Power. Seperti yang diungkapkan oleh 
Wirawan (2015: 136), evaluasi kinerja yang diterima dengan baik oleh para pegawai dapat meningkatkan kepuasan kerja, motivasi kerja, komitmen organisasi, mengurangi tingkat absen, dan pindah kerja (turnover). Demikian sebaliknya apabila evalusi kinerja tidak dapat diterima dengan baik oleh para pegawai dapat menurunkan kepuasan kerja, komitmen organisasi, dan lain-lan. Tetapi pada permasalahan ini penelitian tidak dapat serta merta menyimpulkan bahwa menurunnya komitmen/kepatuhan pegawai PT Indonesia Power disebabkan karena ketidakpuasan pegawai terhadap sistem evaluasi kinerja yang dilakukan oleh perusahaan.

\section{Rumusan Masalah}

Berdasarkan latar belakang masalah yang telah diuraikan sebelumnya, maka rumusan masalah dalam penelitian ini adalah sebagai berikut :

1. Bagaimana evaluasi kinerja yang dilaksanakan PT Indonesia Power?

2. Bagaimana komitmen organisasional pegawai PT Indonesia Power?

3. Bagaimana pengaruh evaluasi kinerja terhadap komitmen organisasional pegawai PT Indonesia Power?

\section{Hipotesis}

Berdasarkan rumusan masalah yang telah diuraikan diatas, maka hipotesis yang diajukan dalam penelitian ini adalah sebagai berikut:

Ha : Terdapat pengaruh yang signifikan dari evaluasi kinerja terhadap komitmen organisasional pegawai.

Ho : Tidak terdapat pengaruh yang signifikan dari evaluasi kinerja terhadap komitmen organisasional pegawai.

\section{KAJIAN LITERATUR Evaluasi Kinerja}

Menurut Marwansyah (2012: 228)

Penilaian kinerja (performance appraisal) adalah sistem formal untuk memeriksa atau mengkaji dan mengevaluasi kinerja seseorang atau kelompok. Sedangkan menurut Wirawan (2015: 11) penialain kinerja adalah proses penilai pejabat yang melakukan penilaian (appraiser) mengumpulkan informasi mengenai kinerja ternilai pegawai yang dinilai (appraise) yang didokumentasikan secara formal untuk menilai kinerja ternilai dengan membandingkannya dengan standar kinerjanya secara periodik untuk membantu pengambilan keputusan manajemen.

Wirawan (2015: 117) menjelaskan persyaratan sistem penilain kinerja yang baik adalah sebagai berikut :

1. Relevansi

Sistem evaluasi kinerja harus relevan, artinya harus ada hubungannya dengan sejumlah faktor organisasi. Pertama, evalusi kinerja harus ada hubungannya dengan strategi dan tujuan organisasi. Kedua, standar kinerja harus ada relevansinya dengan pencapaian strategi organisasi. Indikator kinerja karyawan yang menjadi indikator standar kinerja harus relevan dengan apa yang ingin dicapai tujuan organisasi.

2. Reliabilitas

Reliabilitas artinya konsistensi penilaian dari sistem evaluasi kinerja. Sistem evaluasi kinerja disebut reliabel atau dapat dipercaya jika seorang karyawan yang dinilai oleh dua orang penilai independen mempunyai nilai yang sama atau tidak terlalu berbeda. Jika hasil kedua penilai tersebut sangat berbeda, maka sistem evaluasi kinerja tidak reliabel. Reliabilitas sistem evaluasi kinerja sangat penting karena sistem evaluasi kinerja suatu organisasi akan dipakai dalam waktu yang lama dan berulang-ulang. Reliabilitas evaluasi kinerja dicapai melalui uji coba standar kinerja dan instrumen evaluasi kinerja.

3. Sensitivitas

Evalusi kinerja harus sensitif, artinya dapat membedakan kinerja yang sangat baik, baik, sedang, buruk dan sangat buruk. Jika tidak, maka evaluasi kinerja tidak sensitif. Definisi setiap dimensi terdapat dalam standar kinerja agar 
sistem evaluasi kinerja sensitif. Misalnya untuk dimensi disiplin kerja didefinisikan ukuran disiplin tinggi, sedang, dan buruk dalam standar kinerjanya.

4. Akseptabilitas

Sistem evaluasi kinerja harus akseptabilitas, artinya dapat diterima oleh mereka yang berkaitan denan evaluasi kinerja. Mereka yang berhubugan dengan evaluasi kinerja pertama adalah organisasi atau perusahaan yang membuat sistem evaluasi kinerja tersebut. Organisasi menggunakan evaluasi kinerja untuk mengukur apakah karyawannya melaksanakan pekerjaan dan menghasilkan kinerja seperti yang diharapakannya.

Evaluasi kinerja juga harus diterima oleh karyawan yang dievaluasi. Jika sistem evaluasi kinerja merugikan para karyawan, mereka akan menolak evaluasi kinerja tersebut. Jika karyawan menolak, tetapi perusahaan memaksakannya, maka akan terjadi keresahan, ketidakpuasan dan stres kerja karyawan. Jika fenomena tersebut terjadi, maka kinerja mereka akan merosot. Jika terus dipaksakan, akan terjadi pemogokan. Sistem evalusi kinerja juga harus diterima oleh para manajer yang akan melaksanakannya. Manajer umumnya tidak menyukai sistem evaluasi kinerja yang rumit dan memerlukan waktu untuk melaksanakannya. Sistem evaluasi kinerja seperti itu menyita waktu para manajer sehingga mereka kurang memiliki waktu untuk mengembangkan pekerjaan dalam unitnya. Jika para manajer menolak atau tidak menyukai sistem evaluasi kinerja, mereka tidak akan melaksanakannya atau ogah-ogahan melaksanakannya.

5. Praktikal

Sistem evaluasi kinerja harus praktis artinya mudah dipahami dan dapat dilaksanakan oleh para manejer dengan mudah. Jika tidak praktis makan akan terjadi penolakan dari para manajer atau para karyawan. Praktis tidaknya sistem evaluasi kinerja ditentukan oleh kriteria berikut :

a. Sederhana, evaluasi kinerja harus sederhana, tidak rumit, dan mudah dipahami oleh semua pegawai baik yang terdidik maupun tidak terdidik.

b. Tidak memerlukan waktu banyak (time consuming), pelaksanaan sistem evalusi kinerja tidak memerlukan waktu yang lama setelah pelaksanaan observasi kinerja ternilai.

c. Tidak berisiko tinggi. Risiko evaluasi kinerja antara lain terjadinya sujektivitas dan kesalahan dalam pelaksanaannya. Selain itu, risiko dapat terjadi karena evaluasi kinerja menimbulkan konflik antara penilai dan ternilai.

Menurut Wirawan (2015: 130-131) pelaksanaan evaluasi kinerja perlu memperhatikan norma-norma etika yakni keadilan (justice). Setiap pegawai harus mendapatkan perlakuan yang sama dalam evaluasi kinerja. Dengan kata lain, subjektivitas dalam penilaian harus dihindari oleh penilai. Jika data yang digunakan dalam penilaian bersifat objektif dan dikumpulkan secara tepat, serta wawancara evaluasi kinerja dilakukan sesuai dengan prosedur, maka evaluasi kinerja dapat dilaksanakan dengan jujur. Penilai sering berlaku tidak adil karena penilai membawa nilai-nilai pribadi ke dalam proses evaluasi kinerja. Nilai-nilai pribadi tersebut antara lain prasangka terhadap jenis kelamin, ras, suku bangsa, agama, dan status sosial. Nilai-nilai ini memberikan kontribusi terhadap ketidakobjektifan penilaian penilai.

Keadilan atau justice dalam evaluasi kinerja dapat dikelompokan sebagai berikut:

1. Keadilan prosedural (procedural justice) Keadilan prosedural adalah keadilan mengenai prosedur yang digunakan dalam proses evaluasi kinerja. Dalam manual evaluasi kinerjanya, organisasi umumnya sudah menentukan prosedur dalam melaksanakan evaluasi kinerja. Dalam prosedur itu ditentukan antara lain: kapan evaluasi kinerja harus 
dilakukan, bagaimana prosesnya (proses observasi dan dokumentasi kinerja pegawai, proses penilaian, proses wawancara evaluasi kinerja, dan proses banding), serta apa hak dan kewajiban penilai dan ternilai. Jika prosedur tersebut dilanggar, akan terjadi ketidakadilan prosedural. Prosedur pencapaian hasil yang tidak adil akan menimbulkan ketidakpuasan karyawan yang diperlakukan tidak adil walaupun hasil penilaian evaluasi kinerja adil.

Sistem ketidakadilan prosedural atau system procedural justice juga dapat terjadi. Ketidakadilan terjadi dalam prosedur evaluasi kinerja yang digunakan organisasi. Misalnya, prosedur sistem evaluasi kinerja yang baik memungkinkan karyawan untuk naik banding jika tidak puas dengan nilai kinerja yang diberikan oleh penilai. Jika prosedur evaluasi kinerja yang digunakan organisasi tidak memfasilitasi naik banding, maka terjadi sistem ketidakadilan prosedural.

2. Keadilan distributif (distributive justice) Keadilan ini adalah keadilan atas hasil evaluasi kinerja. Keadilan distributif berisi hasil akhir (the end) atau keputusan akhir evaluasi kinerja. Sementara itu, keadilan prosedural berisi proses (the process) dan alat (the means) yang digunakan untuk mencapai hasil akhir evaluasi kinerja. Keadilan distributif berasal dari teori ekuitas (equity theory) dalam manajemen SDM. Dalam teori ini, seorang karyawan membandingkan rasio input dan output-nya dengan rasio input dan output karyawan lainnya. Jika perbandingan tersebut sepadan, maka terjadi keadilan distributif, jika tidak sepadan terjadilah ketidakadilan distributif. Keadilan distributif akan menentukan keadilan dalam distribusi imbalan sebagai akibat dari nilai evaluasi kinerja. Jika terjadi keadilan distributif, pegawai A dan B akan sama-sama mendapatkan kenaikan gaji atau kenaikan pangkat karena nilai kinerja yang sama.

\section{Komitmen Organisasional}

Menurut Wibowo (2015: 188) komitmen merupakan kesediaan seseorang untuk mengikatkan diri dan menunjukan loyalitas pada organisasi karena merasakan dirinya terlibat dalam kegiatan organisasi. Selain itu, Allen dan Meyer (1997) dalam Priansa (2014: 234) menyatakan bahwa komitmen organisasional merupakan keyakinan yang menjadi pengikat pegawai dengan organisasi tempatnya bekerja, yang ditunjukkan dengan adanya loyalitas, keterlibatan dalam pekerjaan, dan identifikasi terhadap nilai-nilai dan tujuan organisasi.

Menurut Mayer dan Allen (1997) dalam Wibowo (2015: 189) terdapat tiga dimensi komitmen organisasional yaitu :

a. Affective Commitment, menyangkut keterikatan emosional pekerja pada identifikasi dengan dan perlibatan dalam organisasi

b. Continuance Commitment, menyangkut komitmen didasarkan pada biaya yang bersangkutan dengan pekerja dengan meninggalkan organisasi.

c. Normative Commitment, menyangkut perasaan pekerja atas kewajiban untuk tetap tinggal dengan organisasi karena itu merupakan yang terbaik untuk dilakukan.

\section{Kerangka Pemikiran}
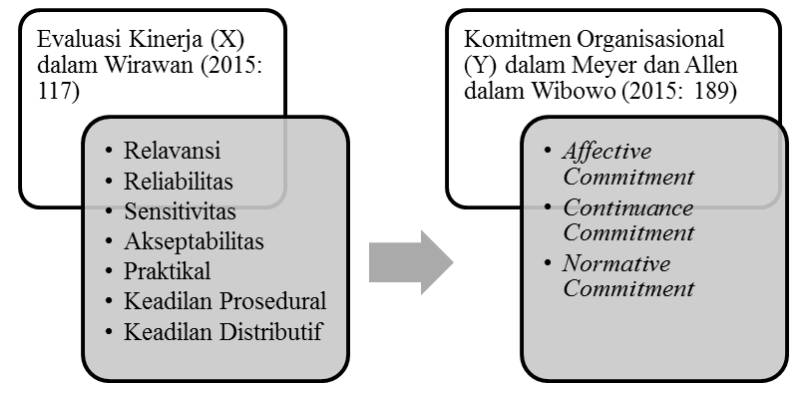

\section{Gambar 2. Kerangka Pemikiran}

\section{METODE}

Metode yang digunakan adalah metode kuantitatif. Hal ini mengacu pada pendapat Sugiyono (2013: 11) yang menyatakan bahwa hubungan sebab akibat (kausal), sehingga dalam penelitiannya ada 
variabel independen dan dependen. Selain itu, Sugiyono (2013: 11) menjelaskan bahwa dari variabel tersebut selanjutnya dicari seberapa besar pengaruh variabel independen terhadap variabel dependen

Populasi pada penelitian ini berjumlah 693 orang yang merupakan seluruh pegawai PT Indonesia Power UBP Suralaya. Teknik sampling digunakan adalah teknik Non Probability Sampling dengan metode yang digunakan adalah Incidental Sampling. Jumlah anggota sampel yang diambil dalam penelitian ini sebanyak 195 orang responden dari $\mathrm{N}=700$ orang dengan taraf kesalahan $10 \%$. (berdasarkan pada tabel yang dikembangkan oleh Issac dan Michael). Data penelitian terdiri dari data primer yaitu kuesioner dan wawancara, serta data sekunder yaitu buku, jurnal, dan dokumen perusahaan.

Tabel 2 Identitas Responden

\begin{tabular}{|c|c|c|}
\hline \multirow{2}{*}{$\begin{array}{c}\text { Jenis } \\
\text { Kelamin }\end{array}$} & Laki-laki & 133 \\
\hline & Perempuan & 62 \\
\hline \multirow{5}{*}{ Usia } & $<25$ Tahun & 41 \\
\hline & 25 - 35 Tahun & 55 \\
\hline & 36 - 45 Tahun & 59 \\
\hline & 46 - 55 Tahun & 40 \\
\hline & $>55$ Tahun & 0 \\
\hline \multirow{5}{*}{$\begin{array}{c}\text { Pendidikan } \\
\text { Terkahir }\end{array}$} & SLTA & 41 \\
\hline & D3/Akademik & 55 \\
\hline & S1/D4 & 59 \\
\hline & S2 & 40 \\
\hline & S3 & 0 \\
\hline \multirow{5}{*}{$\begin{array}{c}\text { Golongan/ } \\
\text { Jabatan }\end{array}$} & Eksekutif & 0 \\
\hline & Penyelia Atas & 25 \\
\hline & Penyelia Dasar & 54 \\
\hline & Pelaksana Senior & 51 \\
\hline & Pelasana & 65 \\
\hline \multirow{6}{*}{ Masa Kerja } & $<5$ Tahun & 41 \\
\hline & 5 - 10 Tahun & 32 \\
\hline & 10 - 15 Tahun & 31 \\
\hline & $15-20$ Tahun & 25 \\
\hline & 20 - 25 Tahun & 31 \\
\hline & $>25$ tahun & 35 \\
\hline
\end{tabular}

Kuesioner dalam penelitian ini menggunakan skala likert, dengan bobot nilai
1-5. Uji validitas dan reliabilitas telah dilakukan dengan hasil semua instrumen dinyatakan valid dan reliabel. Uji validitas dilihat dari $\mathrm{r}$ tabel $<\mathrm{r}$ hitung, kemudian uji reliabilitas dilihat dari nilai alpha cronbach > 0,306 . Nilai reliabilitas untuk evaluasi kinerja sebesar 0,949 dan nilai reliabilitas untuk komitmen organisasional sebesar 0,920.

Analisis dilakukan dengan menggunakan uji asumsi klasik (uji normalitas dan uji linieritas), analisis deskriptif, analisis korelasi, analisis regresi, koefisien determinasi, dan uji hipotesis.

\section{HASIL DAN PEMBAHASAN}

\section{Analisis Deskriptif Evaluasi Kinerja}

Berdasarkan hasil analisis deskriptif variabel evaluasi kinerja diperoleh hasil bahwa evaluasi yang dilakukan oleh PT Indonesia Power UBP Suralaya berada pada kategori baik. Menurut Wirawan (2015: 117) persyaratan agar sistem evaluasi kinerja efektif agar menguntungkan organisasi dan karyawannya adalah relavansi, reliabilitas, sensitivitas, akseptabilitas, praktikal, keadilan procedural, dan keadilan distributive.

Tabel 3 Statistik Deskriptif Variabel Evaluasi Kinerja

\begin{tabular}{|l|c|r|r|r|c|}
\hline & N & Min & Max & Mean & $\begin{array}{l}\text { Std. } \\
\text { Dev }\end{array}$ \\
\hline Relevansi & 195 & 3 & 5 & $\mathbf{4 , 1 4}$ & $\mathbf{0 , 4 9 6}$ \\
\hline Reliabilitas & 195 & 2 & 5 & 4,08 & 0,422 \\
\hline $\begin{array}{l}\text { Sensitivi- } \\
\text { tas }\end{array}$ & 195 & 2 & 5 & 3,97 & 0,511 \\
\hline $\begin{array}{l}\text { Akseptabi- } \\
\text { litas }\end{array}$ & 195 & 3 & 5 & 3,91 & 0,489 \\
\hline Praktikal & 195 & 2 & 5 & 4,03 & 0,483 \\
\hline $\begin{array}{l}\text { Keadilan } \\
\text { Prosedural }\end{array}$ & 195 & 2 & 5 & $\mathbf{3 , 8 2}$ & $\mathbf{0 , 6 3 3}$ \\
\hline $\begin{array}{l}\text { Keadilan } \\
\text { Distributif }\end{array}$ & 195 & 2 & 5 & 3,91 & 0,500 \\
\hline $\begin{array}{l}\text { Evaluasi } \\
\text { Kinerja }\end{array}$ & 195 & 3 & 5 & $\mathbf{3 , 9 8}$ & $\mathbf{0 , 3 5 0}$ \\
\hline
\end{tabular}

Setiap dimensi yang digunakan dalam pengukuran evaluasi kinerja ini berada pada tingkat yang baik. Namun dimensi dengan mean tertinggi adalah dimensi relevansi yaitu 
sebesar 4,14 yang artinya dimensi relevansi berada pada skala interval baik. Menurut Sedarmayanti (2010: 266) relevansi merupakan sistem penilaian yang digunakan untuk mengukur hal atau kegiatan yang ada hubungannya, hubungan yang ada kesesuaian antara hasil pekerjaan dan tujuan yang telah ditetapkan lebih dahulu. Sedangkan dimensi keadilan procedural menjadi dimensi yang memiliki nilai mean terendah yaitu sebesar 3,82 meskipun pada posisi mean terendah tetapi dimensi keadilan prosedural tetap berada pada interval dengan kategori baik. Menurut Wirawan (2015: 131) keadilan distributif merupakan keadilan atas hasil evaluasi kinerja.

Berdasarkan hasil analisis deskriptif, dimensi relevansi termasuk ke dalam kategori baik dengan demikian dapat disimpulkan bahwa karyawan PT Indonesia Power UBP Suralaya merasa bahwa pelaksanaan evaluasi kinerja perusahaan telah dilakukan secara relevan. Berdasarkan hasil pengamatan dan wawancara penulis dalam penelitian ini sistem evaluasi kinerja yang dilakasanakan di PT Indonesia Power UBP Suralaya dikatakan telah relevan didukung dengan adanya Key Performance Indicator (KPI) yang dimiliki oleh PT Indonesaia Power UBP Suralaya.

Interpretasi dimensi keadilan prosedural berada pada tingkat yang baik. Namun, dimensi prosedural merupakan dimensi dengan nilai mean terendah pada variabel evaluasi kinerja dibandingkan dengan dimensi lainyanya. Berdasarkan hasil pengamatan penulis dan hasil wawancara yang dilakukan dalam penelitian ini, pada dasarnya sistem evaluasi kinerja PT Indonesia Power UBP Suralaya telah diatur dalam keputusan Direksi No 80.K/010/IP/2012 tentang sistem manajemen kinerja pegawai. Dalam peraturan tersebut telah atur mengenai perencanaan kinerja pegawai, pemantauan kinerja pegewai, pengukuran kinerja pegawai, ketentuan mengikuti penilaian kinerja termasuk sanksi dan pelanggaran. Namun meskipun dimensi ini memiliki nilai mean yang berada pada kategori baik, tetapi dari keseluruhan dimensi yang digunakan dalam variabel evaluasi kinerja pada penelitian ini, dimensi keadilan prosedural merupakan dimensi dengan nilai mean terendah. Hal tersebut sejalan dengan latar belakang penelitian berdasarkan survey mengenai pelaksanaan evaluasi kinerja yang menunjukaan bahwa sebagian karyawan merasa tidak adanya keterbukaan atasan atas prosedur dalam melakukan evaluasi kinerja. Seharusnya atasan melakukan evaluasi kinerja sesuai dengan peraturan yang telah ditentukan dalam evaluasi kinerja. Adanya keterbukaan pada saat proses evaluasi kinerja dan adanya keterbukaan atas hasil evalusi kinerja kepada karyawan akan membuat karyawaan merasa adanya keadilan dalam prosedur penilaian kinerja dan akan berdampak pada kepuasan karyawan terhadap evaluasi kinerja yang dilakukan.

\section{Analisis Deskriptif Komitmen Operasional}

Untuk menganalisa komitmen organisasional digunakan dimensi Affective Commitment, Continuance Commitment, dan Normative Commitment menurut Meyer dan Allen dalam Wibowo (2015: 189).

Tabel 4 Statistik Deskriptif Variabel Komitmen Organisasional

\begin{tabular}{|l|r|r|r|r|c|}
\hline & N & Min & Max & Mean & $\begin{array}{l}\text { Std. } \\
\text { Dev }\end{array}$ \\
\hline $\begin{array}{l}\text { Affective } \\
\text { Commitment }\end{array}$ & 195 & 3 & 5 & 4,00 & 0,515 \\
\hline $\begin{array}{l}\text { Continuance } \\
\text { Commitment }\end{array}$ & 195 & 3 & 5 & 3,97 & 0,480 \\
\hline $\begin{array}{l}\text { Normative } \\
\text { Commitment }\end{array}$ & 195 & 3 & 5 & 3,90 & 0,501 \\
\hline $\begin{array}{l}\text { Komitmen } \\
\text { Organisasional }\end{array}$ & 195 & 3 & 5 & 3,96 & 0,405 \\
\hline
\end{tabular}

Nilai mean variabel komitmen organisasional menunjukan angka sebesar 3,96 atau berada pada kategori tinggi. Dari tiga dimensi dalam variabel evaluasi kinerja, dimensi Normative Commitment merupakan dimensi dengan nilai mean terendah yaitu sebesar 3,90. Sedangkan dimensi yang 
memiliki nilai mean tertinggi yaitu dengan mean sebesar 4,00 adalah dimensi Affective Commitment.

Interpretasi dimensi affective commitment berada pada interval dengan kategori tinggi. Nilai mean yang tinggi pada dimensi affective commitment menunjukan bahwa responden selaku pegawai PT Indonesia Power UBP Suralaya memiliki komitmen afektif yang tinggi terhadap perusahaan artinya sebagian besar responden merasa bahwa secara pribadi mereka mempunyai keterikatan emosional dengan perusahaan dan merasa bahwa mereka memiliki keterlibatan dengan perusahaan atau organisasi. Menurut McShane dan Von Glinow (2010: 113) Employee involvement, perlibatan pekerja dapat meningkatkan affective commitment dengan memperkuat identitas sosial pekerja dengan organisasi.

Berdasarkan pengamatan penulis hal yang mengindikasikan adanya keterlibatan dengan perusahaan dari masing-masing karyawan karena di PT Indonesia Power UBP Suralaya memiliki job involvement program atau program yang merupakan cara melibatkan pekerja dalam aspek pengambilan keputusan korporasi, selain itu terdapat program-program yang menjadikan adanya kebersamaan antara pegawai Indonesia Power UBP Suralaya antara lain family gathring yang mengindikasikan terbentukanya keterikatan emosional baik antar pegawai maupun pegawai dengan perusahaan.

Dimensi normative commitment pada variabel komitmen organisasional menunjukan nilai mean sebesar 3,90 artinya dimensi normative commitment berada pada kategori tinggi. Dimensi normative commitment memiliki dua indikator yaitu merasa memiliki kewajiban moral dan merasa bahwa loyalitas penting. Menurut Luthans (2011: 73) dalam Wibowo (2015: 189) menjelaskan bahwa normative commitment adalah sebagai keinginan untuk tetap menjadi anggota organisasi karena merasa sebagai kewajiban. Sedangkan menurut Newstrom (2011: 223) normative commitment merupakan pilihan untuk tetap terikat karena budaya yang kuat atau etika familial yang mendorong mereka melakukan demikian. Mereka yakin mereka harus berkomitmen karena norma dan perasaan sebagai kewajiban. Dimensi normative commitment merupakan dimensi yang memiliki nilai mean terendah dibandingkan dengan dimensi lainnya dalam variabel komitmen organisasional pada penelitian ini. Hal tersebut disebabkan karena sebagian kecil karyawan belum merasa puas atas prosedur evaluasi kinerja yang dilakukan oleh atasan, tidak adanya keterbukaan akan prosedur penilaian dan hasil evaluasi kinerja mempengaruhi komitmen organisasional karyawan. Selain itu rendahnya normative commitment karyawan dibandingkan dengan affective commitment dan continuance commitment juga dapat disebabkan oleh faktor internal dari masing-masing karyawan seperti usia, dan masa kerja. Usia dan masa kerja mempengaruhi komitmen karyawan dikarenakan usia yang masih tergolong muda lebih cenderung memiliki komitmen yang kurang terhadap perusahaan.

Tabel 5 Hasil Uji Korelasi Sederhana

\begin{tabular}{|c|c|c|c|}
\hline & & $\begin{array}{c}\text { Evaluasi } \\
\text { Kinerja }\end{array}$ & $\begin{array}{l}\text { Komit- } \\
\text { men } \\
\text { Organisa } \\
\text { sional }\end{array}$ \\
\hline Evaluas & $\begin{array}{l}\text { Pearson } \\
\text { Correlation }\end{array}$ & 1 & $683^{* *}$ \\
\hline & Sig. (2-tailed) & & 000 \\
\hline Kinerja & $\mathrm{N}$ & 195 & 195 \\
\hline $\begin{array}{l}\text { Komit- } \\
\text { men }\end{array}$ & $\begin{array}{l}\text { Pearson } \\
\text { Correlation }\end{array}$ &, $683^{* *}$ & 1 \\
\hline Organis & Sig. (2-tailed) &, 000 & \\
\hline asional & $\mathbb{N}$ & 195 & 195 \\
\hline
\end{tabular}

\section{Analisis Korelasi}

Berdasarkan tabel 5, nilai korelasi antara evaluasi kinerja dengan komitmen organisasional karyawan sebesar 0,683 . Jika mengacu pada tabel interpretasi korelasi menurut Sugiyono (2015: 231), maka nilai 
korelasi sebesar 0,683 termasuk dalam korelasi yang kuat karena berada pada interval 0,60-0,799. Nilai korelasi Pearson pada tabel di atas menunjukan nilai positif. Maka, hubungan antara evaluasi kinerja dengan komitmen organisasional ialah searah. Ini berarti setiap kenaikan evaluasi kinerja maka akan diikuti oleh komitmen organisasional. Karena nilai signifikansi hasil uji korelasi di atas menunjukan 0,000 <0,05, maka dapat disimpulkan bahwa terdapat hubungan yang signifikan antara evaluasi kinerja dengan komitmen organisasional.

\section{Analisis Regresi Linear Sederhana}

Berdasarkan tabel 6, dapat dilihat bahwa konstanta sebesar 9,781 (a) dengan koefisien regresi linear sebesar 0,365 (b). Dari hasi tersebut diperoleh model regresi linear sederhana sebagai berikut.

$$
\begin{aligned}
& \mathrm{Y}=\mathrm{a}+\mathrm{bX} \\
& \mathrm{Y}=9,781+0,365 \mathrm{X}
\end{aligned}
$$

Nilai a dan b di atas dapat diinterpretasikan sebagai berikut :

a. Konstanta sebesar 9,781 dapat diartikan jika evaluasi kinerja sama dengan nol (X $=0$ ) atau tidak ada evaluasi kinerja, maka komitmen organisasional hanya sebesar 9,781.

b. Evaluasi kinerja memiliki nilai koefisien regresi linear sederhana sebesar 0,365. Hal ini mengandung arti apabila evaluasi kinerja mengalami kenaikan satu satuan maka komitmen organisasional akan mengalami kenaikan sebesar 0,365 satuan.

\section{Tabel 6 Hasil Uji Linear Sederhana}

\begin{tabular}{|c|l|c|c|c|c|c|}
\hline \multirow{2}{*}{ Model } & \multicolumn{2}{|c|}{$\begin{array}{c}\text { Unstand. } \\
\text { Coefficients }\end{array}$} & $\begin{array}{c}\text { Stand } \\
\text { Coe }\end{array}$ & \multirow{2}{*}{ S } & Sig \\
\cline { 2 - 5 } & B & $\begin{array}{c}\text { Std. } \\
\text { Err. }\end{array}$ & Beta & & \\
\hline & $\begin{array}{l}\text { (Cons- } \\
\text { tant })\end{array}$ & 9,781 & 2,916 & & 3,355 & 0,001 \\
\cline { 2 - 5 } 1 & $\begin{array}{l}\text { Evalu- } \\
\text { asi } \\
\text { Kinerja }\end{array}$ & 0,365 & 0,028 & 0,068 & 12,990 & 0,000 \\
\hline
\end{tabular}

\section{Koefisien Determinasi}

Tabel 7 Hasil Uji Koefisien Determinasi

\begin{tabular}{|l|c|r|r|c|}
\hline $\begin{array}{l}\text { Mo- } \\
\text { del }\end{array}$ & $\mathbf{R}$ & $\begin{array}{c}\mathbf{R} \\
\text { Square }\end{array}$ & $\begin{array}{c}\text { Adjusted } \\
\text { R Square }\end{array}$ & $\begin{array}{c}\text { Std. } \\
\text { Error of } \\
\text { the Est. }\end{array}$ \\
\hline 1 & 0,683 & 0,466 & 0,464 & 3,558 \\
\hline
\end{tabular}

Berdasarkan tabel 7 diatas, nilai dari koefisien determinasi ( $R$ Square $/ \mathrm{R}^{2}$ ) sebesar 0,466 . Hal itu berarti bahwa sebesar 0,466 atau $46,6 \%$ perubahan komitmen organisasional dapat dijelaskan oleh variabel evaluasi kinerja, sedangakan sisanya 53,4\% dijelaskan oleh sebab-sebab lain yang tidak diteliti dalam penelitian ini.

Tabel 8 Hasil Uji Statistik t

\begin{tabular}{|c|l|c|c|c|c|c|}
\hline \multirow{2}{*}{ Model } & \multicolumn{2}{|c|}{$\begin{array}{c}\text { Unstand. } \\
\text { Coefficients }\end{array}$} & $\begin{array}{c}\text { Stand } \\
\text { Coe }\end{array}$ & \multirow{2}{*}{ t } & \multirow{2}{*}{ Sig } \\
\cline { 2 - 5 } & B & $\begin{array}{c}\text { Std. } \\
\text { Err. }\end{array}$ & Beta & \\
\hline \multirow{2}{*}{1} & $\begin{array}{l}\text { (Cons- } \\
\text { tant) }\end{array}$ & 9,781 & 2,916 & & 3,35 &, 001 \\
\cline { 2 - 5 } & $\begin{array}{l}\text { Evalua } \\
\text { si } \\
\text { Kinerja }\end{array}$ &, 365 &, 028 &, 683 & 12,9 &, 000 \\
\hline
\end{tabular}

Tabel 9 Hasil Uji Statistik F

\begin{tabular}{|l|l|r|r|r|r|r|}
\hline \multicolumn{2}{|c|}{ Model } & $\begin{array}{c}\text { Sum of } \\
\text { Squares }\end{array}$ & df & $\begin{array}{c}\text { Mean } \\
\text { Square }\end{array}$ & F & Sig. \\
\hline \multirow{2}{*}{1} & $\begin{array}{l}\text { Regre } \\
\text { ssion }\end{array}$ & 2135,8 & 1 & 2135,8 & $\begin{array}{r}168, \\
740\end{array}$ &, 000 \\
\cline { 2 - 7 } & $\begin{array}{l}\text { Resid } \\
\text { ual }\end{array}$ & 2442,8 & 193 & 12,657 & & \\
\cline { 2 - 7 } & Total & 4578,7 & 194 & & & \\
\hline
\end{tabular}

\section{Uji Hipotesis}

Dari tabel 8, dapat dilihat bahwa nilai signifikansi pada kolom Sig. untuk evaluasi kinerja adalah sebesar 0,000 . Nilai tersebut lebih kecil dibandingkan dengan nilai probabilitasnya yang nilainya sebesar 0,05 (5\%). Selain itu, dilihat dari nilai t hitung pada kolom $\mathrm{t}$ yang besarnya 12,990 dengan menggunakan tingkat signifikansi 0,05 dan 
df $:(n-k)=195-2=193$, maka diperoleh $\mathrm{t}$ tabel sebesar 1,97233 yang berarti bahwa $t$ hitung > t tabel yaitu 12,990>1,97233. Mengacu pada pendapat Sugiyono (2015) menyatakan bahwa jika nilai thitung $>\mathrm{t}$ tabel dan tingkat signifikansi $<0,05$, maka interpretasinya adalah $\mathrm{H}_{0}$ ditolak dan $\mathrm{H}_{\mathrm{a}}$ diterima. Hal tersebut menunjukan bahwa evaluasi kinerja berpengaruh positif dan signifikan terhadap komitmen organisasional.

Uji statistik $F$ digunakan untuk mengetahui apakah semua variabel independen yang dimasukan ke dalam model mempunyai pengaruh secara bersama-sama terhadap variabel dependen. Hasil dari uji statistik F dapat dilihat pada tabel 9.

Berdasarkan tabel tersebut, dapat dilihat bahwa nilai signifikansi pada kolom Sig. adalah 0,000. Nilai tersebut lebih kecil dibandingkan dengan nilai probabilitasnya yang nilainya sebesar 0,05 (5\%). Apabila dilihat dari nilai $\mathrm{F}$ hitung $\left(\mathrm{F}_{0}\right)$ pada kolom $\mathrm{F}$ sebesar 168,740 dengan menggunakan tingkat signifikansi 0,05 serta $\mathrm{df}_{1}:(\mathrm{k}-1)=2$

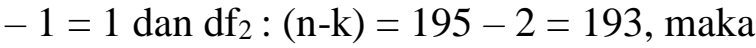
diperoleh $F$ tabel $\left(\mathrm{F}_{\mathrm{t}}\right)$ sebesar 3.89 yang berarti bahwa nilai $F_{0} \geq F_{t}$ yaitu $168,740 \geq$ 3,89. Mengacu pada interpretasi hasil uji statistik F, menurut Arikunto (2010: 368) jika terjadi kriteria $\mathrm{F}_{0} \geq \mathrm{F}_{\mathrm{t}}$, dengan taraf signifikansi $5 \%$ maka interpretasinya adalah $\mathrm{H}_{\mathrm{o}}$ ditolak dan $\mathrm{H}_{\mathrm{a}}$ diterima. Hal tersebut menunjukan bahwa evaluasi kinerja berpengaruh positif dan signifikan terhadap komitmen organisasional.

\section{KESIMPULAN DAN SARAN Kesimpulan}

Berdasarkan hasil analisis dan pembahasan yang telah dilakukan, maka penulis dapat menarik kesimpulan. Kesimpulan tersebut sekaligus menjawab perumusan masalah sebagai berikut:

1. Evaluasi kinerja yang dilakukan di PT Indonesia Power UBP Suralaya termasuk kedalam kategori baik. Kontribusi tertinggi yaitu pada dimensi relevansi, sedangkan kontribusi terendah yaitu pada dimensi keadilan prosedural.

2. Komitmen organisasional karyawan PT Indonesia Power UBP Suralaya berada pada kategori tinggi. Dimensi normative commitment merupakan dimensi dengan kontribusi nilai terendah. Sedangkan dimensi yang memiliki kontribusi tertinggi adalah dimensi affective commitment.

3. Besarnya pengaruh evaluasi kinerja terhadap komitmen organisasional karyawan PT Indonesia Power UBP Suralaya pada penelitian ini sebesar 0,466 atau 46,6\% perubahan komitmen organisasional dapat dijelaskan oleh variabel evaluasi kinerja, sedangkan sisanya 53,4\% dijelaskan oleh sebabsebab lain yang tidak diteliti dalam penelitian ini.

\section{Saran}

Adapun saran yang berikan untuk PT Indonesia Power UBP Suralaya terkait dengan evaluasi kinerja dan komitmen organisasional karyawan adalah sebagai berikut:

1. Untuk meningkatkan keadilan prosedural dalam pelaksanaan evaluasi kinerja baiknya manajemen memberikan arahan kepada penilai agar mengikuti aturan evaluasi kinerja yang telah diatur dalam keputusan direksi dan menjelaskan mengenai sanksi atas pelanggaran yang dilakukan pada saat evaluasi kinerja. Selain itu, penilai harus memberikan kebebasan kepada ternilai untuk mengungkapkan pendapat ataupun menyanggah/banding atas hasil atau pada saat pelaksanaan evaluasi kinerja agar ternilai merasa adanya keterbukaan dan keadilan dalam prosedur pelaksanaan evaluasi kinerja.

2. Untuk meningkatkan normative commitment karyawan Menurut Heller (1999) dalam Wibowo (2015: 191) salah satu cara untuk mendapatkan komitmen pekerja dapat dilakukan dengan cara memenangkan pikiran, semangat dan 
hati. Komitmen penuh dari bawahan tidak dapat direalisir sampai kita menunjukan kebutuhan psikologis, intelektual, dan emosional pekerja. Dengan memberikan bobot seimbang dari ketiga faktor tersebut, kemungkinan kita memenangkan pikiran, semangat dan hati pekerja.

3. Besarnya pengaruh evaluasi kinerja terhadap komitmen organisasional karyawan PT Indonesia Power UBP Suralaya pada penelitian ini sebesar 0,466 atau $46,6 \%$ untuk itu untuk meningkatkan komitmen organisasional karyawan, perusahaan harus memperhatikan faktor lain seperti yang diungkapkan oleh McShane dan Glinow (2000) dalam Priansa (2014: 245) yaitu keadilan dan kepuasan kerja, keamanan kerja pemahaman organisasi, keterlibatan pegawai dan kepercayaan pegawai, sebagai faktor lain yang dapat mempengaruhi komitmen organisasional.

\section{DAFTAR PUSTAKA}

Allen, N. J. \& Meyer, J. P. (1993). Organizational commitment: Evidence of Career Stage Effects. Journal of Business Research, 26, 49-61

Marwansyah. (2012). Manajemen Sumber Daya Manusia Edisi Kedua. Bandung: CV. Alfabeta.

Neha, S., \& Himanshu, R. (2015). Impact of Performance Appraisal on Organizational Commitment And Job Satisfaction. International journal of engineering and management sciences (I.J.E.M.S). VOL.6 (2) 95 - 104. 2229$600 \mathrm{X}$.

O, F., \& Seidu, P. A. (2012). Employees' Perception of Performance Appraisal System: A Case Study. International
Journal of Business and Management Vol. 7, No. 2.

Priansa, D. J. (2014). Perencanaan dan Pengembangan Sumber Daya Manusia. Bandung: Alfabeta.

Sedarmayanti. (2010). Manajemen Sumber Daya Manusia, Reformasi Birokrasi, dan Manajemen Pegawai Negeri Sipil. Bandung: PT Refika Aditama.

Singh, P., \& Rana, S. (2013). The Impact of Performance Appraisal on Organizational Commitment of Bank Employees. International Journal of Science and Research (IJSR). 2319-7064

Sugiyono. (2015). Statistika Untuk Penelitian. Bandung: CV Alfabeta

Sugiyono. (2013). Statistika Untuk Penelitian. Bandung: CV. Alfabeta

Wibowo. (2015). Perilaku Dalam Organisasi edisi ke 2. Jakarta: Rajawali Pers.

Wijayanti, A., \& Wimbarti, S. (2012). Evaluasi Dan Pengembangan Sistem Penilaian Kinerja Pada PT HKS. Jurnal Psikologi Undip Vol. 11, No.2

Wirawan. (2015). Evaluasi Kinerja Sumber Daya Manusia, teori aplikasi dan penelitian. Jakarta: Salemba Empat. 